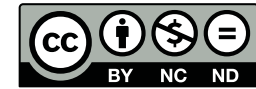

Estudos Teológicos foi licenciado com uma Licença Creative Commons Atribuição - NãoComercial - SemDerivados 3.0 Não Adaptada

http://dx.doi.org/10.22351/et.v.57i2.2982

\title{
TeOlogia POLÍtica da Reforma: Calvino, Calvinistas e RevoluCionários ${ }^{1}$
}

\author{
Political theology of Reformation: \\ Calvin, Calvinists and revolutionaries
}

\begin{abstract}
Wanderley Pereira da Rosa ${ }^{2}$
Resumo: O texto apresenta a evolução da teoria política do reformador João Calvino, de uma visão subserviente ao Estado, mesmo que tirânico, até a possibilidade da resistência armada, liderada pelos magistrados inferiores em caso de grave ameaça à fé. Coube aos calvinistas ingleses e escoceses romper esses limites, advogando a possibilidade de resistência popular, uma vez que o poder dos governantes tem sua origem no povo. $\mathrm{O}$ caminho percorrido passou pelas guerras religiosas que assolaram a Europa nos séculos XVI e XVII, os movimentos populares na Inglaterra (XVII) e a defesa pela tolerância religiosa. A partir de bases teológicas, as teorias políticas secularizaram-se e se tornaram o fundamento das modernas democracias.
\end{abstract}

Palavras-chave: Teologia política. Protestantismo e democracia. Calvinismo e política.

Abstract: This paper presents the evolution of John Calvin's political theory, from a subservient view to the State, even tyrannical, to the possibility of armed resistance, led by lower magistrates in case of serious threat to faith. English and Scottish Calvinists broke these limits, advocating the possibility of popular resistance, since the power of rulers has its origin in the people. The road traveled through the religious wars that ravaged Europe in the sixteenth and seventeenth centuries, popular movements in England (XVII) and defense for religious tolerance. From the theological foundations, political theories were secularized and became the foundation of modern democracies. Keywords: Political Theology. Protestantism and democracy. Calvinism and politics.

1 O artigo foi recebido em 27 de março de 2017 e aprovado em 16 de outubro de 2017 com base nas avaliações dos pareceristas ad hoc.

2 Mestre em Teologia pela Faculdades EST (São Leopoldo/RS, Brasil), doutor em Teologia pela PUC-Rio (Rio de Janeiro/RJ, Brasil), é diretor-geral da Faculdade Unida de Vitória, Vitória/ES, Brasil. Contato: wanderley@faculdadeunida.com.br 


\section{Introdução}

O objetivo deste artigo é demonstrar como teorias políticas embrionárias, nascidas no seio da teologia calvinista (não de forma exclusiva), evoluíram para o estabelecimento das bases para as modernas filosofias políticas de caráter secular.

\section{A teologia política de João Calvino}

João Calvino ${ }^{3}$ dedica algumas páginas do livro quatro de sua magnum opus $A$ Instituição da Religião Cristã, comumente conhecida como As Institutas, à sua ética política. Calvino não tem dúvidas de que toda autoridade humana é instituída por Deus e, à semelhança de Lutero, recorre várias vezes ao clássico texto de Paulo em Romanos 13 e afirma que "não se deve, pois, ter a menor dúvida de que o poder civil é uma vocação não somente santa e legítima diante de Deus, mas também deveras sacrossanta e honrosa entre todas as demais"4.

Devemos recordar que a primeira edição das Institutas (1536) foi publicada no calor dos terríveis acontecimentos de Münster. ${ }^{5}$ Assim, percebemos em seu texto uma constante reprimenda às posturas políticas dos anabatistas e radicais. Eles são "amantes de utopias" e consideram uma indignidade "ocupar-nos dessas solicitudes

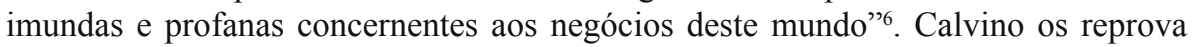
porque "não se satisfazem com os testemunhos da Escritura e criticam ofensivamente esta santa vocação como se fosse totalmente contrária à religião e à piedade cristãs, que outra coisa fazem senão insultar o próprio Deus" ". Para Calvino, "esse tipo de gente não reprova os seus superiores, rejeitando o seu governo, mas rejeita totalmente a Deus". E completa afirmando que a repreensão divina virá sobre eles, que "falam

3 Reformador francês que, em função de suas convicções protestantes, teve que fugir da França para se refugiar na cidade suíça de Basileia, em 1534. Mais tarde, estabeleceu-se em Genebra, local em que colocou em prática, até a sua morte em 1564, sua visão da Reforma.

4 Cf. CALVINO, João. As Institutas. São Paulo: Cultura Cristã, 2006. Livro IV, Capítulo XVI, seção 7, p. 150. Para o presente trabalho foi utilizada a tradução da edição francesa de 1941. Devem-se considerar as edições posteriores para eventuais avaliações do pensamento de Calvino sobre o assunto aqui abordado.

5 No início da década de 1530, a cidade de Münster fora dominada por anabatistas seguidores das ideias escatológicas de Melchior Hoffman. Eles eram liderados por Jan Matthys, que proclamou que ali seria fundado o Reino de Jerusalém. Todos aqueles que não aderiram ao movimento foram expulsos da cidade ou executados, a poligamia foi instituída, a comunhão de bens passou a ser regra e um governo teocrático foi instalado. Com forte inspiração veterotestamentária, os anabatistas de Münster foram liderados nos últimos dias pelo autoproclamado rei Jan van Leiden, após a morte de Matthys em batalha contra as tropas do bispo católico. Leiden pregava a vingança de Deus contra os infiéis. Seu reino não se submeteria às autoridades seculares. Após o cerco da cidade, famintos e sem auxílio externo, os habitantes foram massacrados em 1535. A experiência de Münster ficou marcada como uma história de intolerância e terror com motivações religiosas e sociais.

6 CALVINO, 2006, IV, XVI, seção 2, p. 146.

7 CALVINO, 2006, IV, XVI, seção 9, p. 151. 
mal de todas as autoridades ordenadas por Deus", assim como foi feito com o povo de Israel que rejeitara Samuel. ${ }^{8}$

É verdade que as autoridades seculares devem ter em mente "que são vigários de Deus" e, portanto, "os que governam são constituídos protetores e mantenedores da tranquilidade, da honestidade, da inocência e da modéstia públicas, e devem ocupar-se em manter o bem-estar geral e a paz comum" ${ }^{\prime 10}$. Por outro lado, para garantirem o bem-estar social, eles também são "revestidos de poder, para reprimir e punir rigorosamente os malfeitores, por cuja maldade é perturbada a paz pública"11. Daí que, para Calvino, a pena de morte é legítima, pois "ao punir, a autoridade não faz nada de si próprio, mas apenas executa os juízos de Deus [...]"12. Por conseguinte, quando a autoridade terrena exercita a justiça, ou seja, aplica a pena de morte, está, em verdade, aplicando a justiça de Deus. Ato contínuo, a guerra, quando em defesa contra uma agressão externa, também é legítima, pouco importando "se o invasor é rei ou plebeu"13.

Isso remete à situação de um governo injusto e tirânico. Como deverá o cristão agir em tal caso? Para o reformador de Genebra, tais governantes são ordenados por Deus para "punir a iniquidade do povo"14. Por isso não devemos hesitar em "dar a um tirano, por mau que seja, a honra da qual o Senhor o terá feito digno"15. Isso porque Deus lhes "conferiu majestade inviolável"16. Ao final, Calvino abre uma exceção ao ressalvar que "tal obediência não nos afaste da obediência àquele sob cuja autoridade é lógico que todos os desejos dos reis se contenham". Nesse caso, "se eles ordenarem alguma coisa que vá contra ele [Deus], não lhes devemos dar a mínima atenção"17.

Mas as coisas começaram a mudar a partir da metade do século XVI. A Reforma Protestante estava ameaçada em toda a Europa. Os governantes católicos envidaram esforços para restaurar a antiga fé e unidade religiosas. Na Alemanha, no ano seguinte à morte de Lutero (1546), eclodiu finalmente a guerra das tropas imperiais contra os príncipes alemães luteranos, unidos na Liga de Esmalcalda. Essas guerras germânicas cessaram somente em 1555, com a assinatura da Paz de Augsburgo. Na Inglaterra, a Reforma Protestante avançou durante o governo de Eduardo VI, ladeado pelo tio protestante, o duque de Somerset, e sob a liderança do arcebispo Tomás Cranmer. Mas com a morte do jovem monarca, subiu ao trono sua irmã mais velha, Maria Tudor (1553-1558), período em que os protestantes enfrentaram o terror, quando cerca de 300 deles foram queimados nas fogueiras.

$\mathrm{Na}$ Escócia, após avanços significativos dos protestantes, com a mudança no cenário político, fruto da aliança entre escoceses e franceses contra a Inglaterra em

\footnotetext{
Cf. CALVINO, 2006, IV, XVI, seção 9, p. 151.

CALVINO, 2006, IV, XVI, seção 8, p. 150.

${ }^{10}$ CALVINO, 2006, IV, XVI, seção 11, p. 153.

${ }^{11}$ CALVINO, 2006, IV, XVI, seção 11, p. 153.

${ }_{12}$ CALVINO, 2006, IV, XVI, seção 12, p. 154.

${ }^{13}$ CALVINO, 2006, IV, XVI, seção 13, p. 157.

${ }^{14}$ CALVINO, 2006, IV, XVI, seção 29, p. 169.

${ }^{15}$ CALVINO, 2006, IV, XVI, seção 30, p. 170.

${ }^{16}$ CALVINO, 2006, IV, XVI, seção 32, p. 172.

${ }^{17}$ CALVINO, 2006, IV, XVI, seção 35, p. 175.
} 
fins da década de 1540, a Igreja Católica voltou a dominar o país, em um movimento que culminou com a subida ao poder da rainha católica Maria de Guise. Nesse período, iniciadas as perseguições, o reformador John Knox, feito prisioneiro, foi enviado para trabalhar nas galés. Igualmente na França, após um breve período de relativa tranquilidade, os huguenotes, protestantes franceses, tornaram-se alvos da perseguição do rei Francisco I, que, em 1540, determinou a cassação e execução de todos os hereges. Os sucessivos governos de Henrique II e dos Guise intensificaram as perseguições, mergulhando o país numa guerra religiosa. ${ }^{18}$

A crise enfrentada pelos protestantes nesse período levou os luteranos a reafirmar as teses de resistência ativa formuladas nos inícios de $1530 .{ }^{19}$ Finalmente, Calvino, já no final da vida, reviu a antiga posição e passou a admitir uma teoria revolucionária. O que Calvino e seus colegas passaram a defender era basicamente a teoria constitucional defendida por Lutero e os luteranos, que admitia uma oposição por parte dos magistrados inferiores. ${ }^{20}$ Skinner destaca que foi publicado em $1550 \mathrm{o}$ mais importante documento a reafirmar essa teoria - Confissão e apologia dos pastores e outros ministros da Igreja em Magdeburgo, de autoria do amigo de Lutero, Nicolas von Amsdorf. Esse autor ainda lembra que alguns consideram esse texto "a primeira enunciação formal" dos protestantes "de uma teoria de resistência legítima pela força" ${ }^{21}$. Ainda assim, os calvinistas e o próprio Calvino titubearam, se contradisseram, avançaram e recuaram várias vezes nesse tema, ora afirmando a crença na resistência ativa, ora amenizando o tom em prol da mera desobediência pacífica, quando não a completa subserviência.

Mas não será nas Institutas que vamos encontrar as mudanças de opinião mais significativas de Calvino, mas sim nos comentários publicados em seus últimos anos. ${ }^{22}$ Em seu comentário ao livro de Atos dos Apóstolos, sobre a passagem que afirma que é "melhor obedecer a Deus do que aos homens", Calvino diz que "se um rei, príncipe ou magistrado se conduz de modo a diminuir a honra e o direito de Deus,

18 Cf. SKINNER, Quentin. As Fundações do Pensamento Político Moderno. São Paulo: Companhia das Letras, 2009. p. 465-467. Seguimos de perto o pensamento de Quentin Skinner nesta parte do texto.

19 Cf. SILVESTRE, Armando Araújo. Calvino e a Resistência ao Estado. São Paulo: Mackenzie, 2002. p. 148-155.

${ }^{20}$ Para um detalhamento acerca dessas posições semelhantes entre Calvino e Lutero, remetemos ao texto ROSA, Wanderley Pereira da. A Teologia Política de Lutero. Horizonte, Belo Horizonte, v. 14, n. 44, p. 1.210-1.229, out./dez. 2016.

21 SKINNER, 2009, p. 483.

22 "Mas, se passarmos das Institutas aos comentários sobre a Bíblia que ele veio a publicar nos derradeiros anos de sua vida, veremos que então começava a dar maior alcance a suas referências ao argumento do direito privado, transformando-o numa teoria da legítima oposição aos tiranos." Não devemos nos esquecer também do destaque feito por Skinner de que, na última edição das Institutas (1559), Calvino acrescentou uma única frase que sugere que o governante tirânico perde a legitimidade. SKINNER, 2009, p. 494. Encontramos essa citação no texto de Armando Silvestre: "se uma ordem civil de leis e instituições (politia, polices) garantir a atuação dos magistrados do povo, estes poderiam resistir coletivamente aos tiranos". Apud SILVESTRE, 2002, p. 160. Cf. também HÖPFL, Harro. Lutero e Calvino - sobre a autoridade secular. São Paulo: Martins Fontes, 2005. p. XXVII. 
converte-se em nada mais do que um homem comum"23. Em seu comentário a Daniel, novamente lembra que, quando um príncipe se volta contra Deus, perde sua autoridade e não precisa mais ser obedecido: "que nos mantenhamos sob a Palavra de Deus e nunca sejamos removidos de uma fé genuína, jamais nos amolecendo com a força de uma constância invencível, não importa o que os reis ordenem" 24 . Ao comentar o capítulo 6.21,22, passagem que descreve o momento em que Daniel não foi devorado pelos leões, Calvino deixa claro que em sua visão a obediência ao governante deveria submeter-se à obediência maior à Deus:

Sabemos que os impérios terrenos são estabelecidos por Deus, porém com a condição que não se detraia dele nada, e que só ele seja supremo, e assim todos os governantes e os grandes do mundo se veem forçados, em suas posições, a submeter-se a sua glória. Portanto, já que Daniel não podia obedecer ao edito real sem renegar a Deus, como vimos anteriormente, ele não cometia pecado contra o rei [...]. E para que isso se torne ainda mais claro, devemos lembrar-nos das palavras de Pedro: "Temei a Deus, honrai ao rei”. Essas duas coisas estão entrelaçadas e não podem separar-se uma da outra. Desse modo, o temor do Senhor deve vir primeiro, se é que os reis desejam manter sua autoridade. [...] Portanto, em primeiro lugar, que Deus seja temido; os príncipes terrenos manterão sua autoridade, mas de forma tal que Deus seja sempre supremo $[\ldots]^{25}$.

O reformador de Genebra vai além e afirma que "quando eles [os príncipes] se insurgem contra Deus", "é necessário que sejam derrubados"26. Isso não significa que, para Calvino, o povo poderia se rebelar em de forma individual ou coletiva. A resistência armada, quando necessária, segundo ele, sempre seria restrita aos magistrados inferiores. ${ }^{27}$

Em Teodoro de Beza, amigo e continuador de obra de Calvino em Genebra, já encontramos um avanço nas teorias de resistência ativa aos governantes. A esse respeito, John Witte Jr. afirma que o argumento de Beza pode ser resumido no seguinte: "Quando o oficial político já não respeita esse cargo e não representa Deus no mundo, o 'consentimento público' pode dar lugar à 'dissidência pública"" 28 . Ainda assim, para Beza, "a tirania só pode ser derrubada pela ação dos nobres, que deverão pegar em armas para deter aqueles que já não governam pela paz e tranquilidade do povo" ${ }^{29}$.

${ }^{23}$ Apud SKINNER, 2009, p. 494.

${ }^{24}$ CALVINO, João. Daniel. São Paulo: Parakletos, 2000. v. 1, p. 193.

${ }^{25}$ CALVINO, 2000, p. 398.

${ }^{26}$ Apud SKINNER, 2009, p. 495.

${ }^{27}$ Cf. CALVINO, 2006, IV, XVI, seção 34, p. 174, 175.

28 Apud MORAES, Gerson Leite de. Entre a Bíblia e a Espada - uma análise da filosofia e da teologia política em João Calvino. São Paulo: Mackenzie, 2014. p. 217.

29 MORAES, 2014, p. 220. 


\section{Do religioso ao secular - teologia política de calvinistas radicais posteriores}

Postura bem mais contundente encontraremos nos calvinistas ingleses e escoceses, de atitude explicitamente revolucionária ${ }^{30}$ : "No reino insular, procede-se a uma enunciação totalmente inequívoca do argumento do direito privado como a principal justificativa para legitimar-se a resistência pela força" ${ }^{\text {31 }}$. Skinner, a esse respeito, destaca dois líderes calvinistas ingleses: John Ponet, que escreveu um Breve tratado sobre o poder politico, e Cristopher Goodman, em seu Como os poderes superiores devem ser obedecidos por seus súditos. Com algumas diferenças, ao final ambos legitimam a resistência armada. Goodman foi mais vigoroso em sua defesa, encerrando um dos capítulos de sua obra com as seguintes palavras: "Reis e governantes tornam-se de todo blasfemadores contra Deus, e opressores e assassinos de seus súditos", então "devem ser considerados não mais reis ou legítimos magistrados, mas pessoas privadas, e ser examinadas, acusadas, condenadas e punidas pela lei de Deus, à qual estão e têm de estar sujeitas"32.

Esses autores e também John Knox ampliam a ideia de Calvino de resistência ativa restrita aos magistrados inferiores e defendem a revolução popular. Para Goodman, cabe a "toda pessoa, de alta ou baixa condição", em caso de omissão dos magistrados, "manter e defender essas mesmas leis" contra toda tirania. Para Knox, é dever sagrado imposto pelo próprio Deus não apenas aos "reis e principais governantes", mas também a "todo o conjunto do povo" lutar contra a idolatria e a tirania. ${ }^{33}$

Essa referência à idolatria feita por John Knox remete ao vínculo que esses calvinistas radicais faziam até então entre os governantes e seu dever de defender a verdadeira fé. Mas o pensamento calvinista evoluiu rumo a uma "teoria da revolução inteiramente política" sem o viés religioso como justificativa para a revolta popular. Para Skinner, essa evolução estava "alicerçada numa tese moderna e secularizada acerca dos direitos naturais e da soberania original do povo" 34 . Se o primeiro passo nessa direção foi dado por huguenotes, sua plena concretização deu-se na Escócia. $\mathrm{O}$ contexto propício para essa virada foi a deposição, em 1567, da rainha católica Maria Stuart, que resistira no trono mesmo depois que o Parlamento da Reforma oficializou, em 1560, a adoção da fé calvinista no país. Seria legítima essa deposição? George Buchanan (1506-1582) respondeu afirmativamente na obra $O$ direito do reino entre os escoceses, texto tremendamente influente, publicado em 1579.

Como humanista que era, Buchanan recorre a Cícero para discorrer sobre a condição natural dos seres humanos que viviam, tal como criados, isolados, errantes

\footnotetext{
${ }^{30}$ A esse respeito, Harro Höpfl afirma que "em sua obra posterior, Calvino não acrescentou nada mais à doutrina da resistência; os desenvolvimentos significativos que ela recebeu em círculos calvinistas foram obra de seus seguidores na França, na Holanda e em outros lugares”. HÖPFL, 2005, p. XXVIII.

31 SKINNER, 2009, p. 496.

32 Apud SKINNER, 2009, p. 499.

33 Apud SKINNER, 2009, p. 511.

34 SKINNER, 2009, p. 607-608.
} 
"sem possuir leis nem morada fixa". Portanto as sociedades políticas como as conhecemos não foram ordenadas por Deus, mas são fruto de consensos e decisões tomadas pelos próprios seres humanos. Buchanan não mais recorre a argumentos religiosos ou teológicos para explicar as relações sociais e políticas. Trata-se agora de ciência política pura e simplesmente. Daí que a constituição de governos sobre as sociedades é também uma decisão soberana do povo que, de maneira alguma, abdica desse poder.

Também essencial para essa transição entre a fundamentação religiosa das teorias políticas para uma base secular encontramos no filósofo e teólogo calvinista alemão Johannes Althusius em sua obra Política. Althusius dedica o capítulo 38 a analisar os abusos dos governantes tirânicos e como afastar tais males. "Como defensor das associações, ele sublinha a soberania popular como algo inalienável e reforça o veto contra toda e qualquer tentativa de subtraí-la aos seus legítimos proprietários." ${ }^{35}$ Para ele, o direito à resistência pertence ao povo coletivamente, e não individualmente, "e em seu nome, aos Éforos"36. Althusius não deixa dúvidas sobre sua concepção federalista de poder e de soberania do povo ao afirmar que "da mesma forma que eles têm o direito de criar o magistrado, por consentimento e mandato do povo, também recebem o direito de julgá-lo e depô-lo"37. Para ele, essa resistência se justifica quando "o tirano está exercendo atos autocráticos"38. Althusius alerta que, antes da luta armada e da deposição, outras soluções devem ser tentadas "até que se provem inócuas, para que o remédio não seja mais perigoso do que a própria doença". A resistência deve iniciar por "meios defensivos, e não ofensivos" e "deve ser feita com palavras e atos" e, finalmente, "com a força e as armas [...] quando é atingido um ponto que, sem a força armada, não se pode restringir, confinar ou afastar tal tirania"39.

Com a evolução da filosofia política calvinista descrita até aqui, estava aplainado o caminho para as importantes revoluções sociais e políticas que ocorreram ao longo do século XVII na Inglaterra. No centro desses conflitos, que também eram de ordem religiosa, estavam os puritanos.

\section{A teologia política de puritanos calvinistas ingleses no século XVII}

Se muitos puritanos optaram por permanecer na igreja oficial (anglicana), outros tantos romperam com o anglicanismo e fundaram igrejas livres que expressavam suas próprias crenças e ideais do verdadeiro cristianismo. Ora, o que pretendemos mostrar é que o surgimento da democracia na Grã-Bretanha está intimamente vinculado aos desdobramentos dessa história. Os anglicanos, com seu sistema de governo episcopal, serão os mais identificados com o absolutismo monárquico. Os puritanos congregacionalistas e, mais tarde, também os batistas e os quakers, com seus ideais de comunidades sobera-

${ }^{35}$ ROMANO, Roberto. Os Monarcômacos. 2008. Disponível em: <https://robertoromanosilva.wordpress. com/2010/03/11/os-monarcomacos/>. Acesso em: 31 ago. 2017.

36 ROMANO, 2008.

37 ALTHUSIUS, Johannes. Política. Rio de Janeiro: Topbooks, 2003. p. 352.

38 ALTHUSIUS, 2003, p. 353.

39 ALTHUSIUS, 2003, p. 355. 
nas, lutarão aguerridamente pelo estabelecimento da democracia. Os presbiterianos, que optaram por um sistema cujas comunidades elegem autoridades superiores, sem abdicar da soberania, defenderão uma monarquia parlamentarista. A eclesiologia de cada um desses grupos servirá de referência para diferentes propostas de organização política. Como atesta André Biéler, "são suas diferenças de visão sobre a Igreja que os levarão também a divergências de opinião sobre a estrutura da sociedade"

Com a morte da rainha Elizabeth e a subida ao trono do seu primo, o rei da Escócia James VI (James I da Inglaterra), a situação não melhorou para os puritanos. Sua política desastrosa deu início à exclusão dos calvinistas da Igreja Anglicana, acentuando suas feições católicas. O monarca dependia dos Lordes e dos Comuns para o aumento de cobranças de impostos, mas não tinha habilidade ou paciência para negociações políticas. Desejava reinar com poder supremo. Seu filho Carlos I, que o sucedeu, aprofundou a crise e governou sem o Parlamento de 1629 a 1640. Em um cenário marcado pelos cofres vazios, a revolta dos escoceses, que reagiram à tentativa de imposição do governo episcopal à sua igreja presbiteriana e à crueldade contra puritanos, sucessivamente executados, eclodiu finalmente a guerra civil em 1642, que culminou com a decapitação do rei, em janeiro de 1649.

Talvez na Inglaterra do século XVII, mais do que em qualquer lugar, ficou claro o quanto a concepção de igreja feita pelos fiéis, sua compreensão de como devem se dar as relações dentro das comunidades de fé, repercutiu no seu ideal de organização política da sociedade. ${ }^{41}$ Os puritanos calvinistas, radicais revolucionários, não podiam tolerar um sistema de governo absolutista. A monarquia contava com a complacência dos anglicanos, membros da igreja oficial, representantes da aristocracia. Havia, assim, de um lado os realistas, e de outro, os parlamentares, "a luta entre o despotismo e as liberdades inglesas", nas palavras de Renato Janine Ribeiro, em sua apresentação do livro O Mundo de Ponta-Cabeça, do historiador inglês Christopher Hill. Em seguida, Janine Ribeiro destaca a novidade trazida por Hill a esse esquema bipolar descrito pela historiografia, que consistia na introdução de um terceiro elemento nesse conflito: as classes populares. ${ }^{42}$

A Inglaterra, sob o reinado de Elizabeth, havia escapado de uma guerra civil como a que assolara a Alemanha e a França em meados do século XVI. Mantivera-se também afastada da Guerra dos Trinta Anos (1618-1648), a última grande guerra religiosa europeia, que vinha assolando o continente, com consequências imprevisíveis. Mas, com a nova política absolutista dos Stuarts, finalmente a conflagração civil eclodiu, opondo o monarca às tropas do Parlamento. Após as derrotas iniciais das tropas populares, essas passaram a ser lideradas pelo congregacionalista Oliver Cromwell, que, organizando o Novo Exército Modelo, mudou o rumo da guerra, derrotando as tropas reais. Após a execução do rei, em 1649, foi instituída a república ou Commonwealth. $\mathrm{O}$ ato de constituição rezava: "O povo é, sob o olhar de Deus, a origem

${ }^{40}$ BIÉLER, André. A Força Oculta dos Protestantes. São Paulo: Cultura Cristã, 1999. p. 40.

${ }^{41}$ Cf. BIÉLER, 1999, p. 76.

${ }^{42}$ Cf. RIBEIRO, Renato Janine. Apresentação. In: HILL, Christopher. O Mundo de Ponta-Cabeça - idéias radicais durante a Revolução Inglesa de 1640. São Paulo: Companhia das Letras, 2002. p. 16. 
de todo o poder justo [...] As comunas da Inglaterra, reunidas no Parlamento, eleitas pelo povo e representando o povo, têm o poder supremo da nação"43. Uma mudança significativa ocorreu nesse momento, com consequências duradouras e basilares para a consolidação da democracia. Os grupos puritanos mais radicais tinham o ideal de construção de um "reino dos santos" separado dos incrédulos. A experiência da guerra civil levou esses grupos a admitir medidas de tolerância religiosa, consentindo com a igualdade de cidadania para todos. Era isso o que representava a Commonwealth. A esse respeito, o historiador inglês Christopher Dawson declarou:

A anuência em tolerar, o grande resultado da complexa experiência inglesa da Guerra Civil e da Commonwealth, foi, em última análise, uma aceitação da derrota. Significava o abandono do ideal puritano do "reino dos santos" e a admissão do princípio do Estado secular. Embora todas as consequências não tenham sido percebidas até o século seguinte, na Era do Iluminismo, as decisões vitais já tinham sido tomadas por Oliver Cromwell (1599-1658) e os líderes puritanos dentre os "independentes" e congregacionalistas em meados do século XVII ${ }^{44}$.

Essa primeira experiência de governo democrático não durou muito. Conflitos internos entre os grupos populares que participaram da guerra, como os ranters e os levellers, levaram Cromwell a assumir cada vez mais poderes absolutos. Nomeado Protetor da Inglaterra em 1657, morreu no ano seguinte, deixando o inábil filho como sucessor. Intervenções dos exércitos escoceses restauraram a monarquia, levando ao trono Carlos II, o filho do falecido rei. Inaugurou-se um período de terríveis perseguições aos não conformistas. Cargos públicos lhes foram vedados e o anglicanismo, restaurado. Milhares de puritanos partiram para a América do Norte em busca de liberdade religiosa. Jaime II sucedeu o irmão e aprofundou o absolutismo e a proteção aos católicos. Não tardou para que fosse deflagrada uma nova reação, a Revolução Gloriosa, de 1688-1689. ${ }^{45}$

Desta feita, os Whigs, partido liberal originário da burguesia protestante, adepta do Parlamento, acorreram ao genro do rei, Guilherme III d'Orange. A mobilização da maioria do país em favor de Guilherme pôs fim ao reinado de Jaime II, revolução sem derramamento de sangue, e estabeleceu-se definitivamente a monarquia parlamentarista, sistema político que caracteriza a democracia inglesa até os dias atuais. Para os novos soberanos, o Parlamento redigiu a famosa Bill of Rights, encerrando a ideia de monarquia por direito divino. De agora em diante, a autoridade do rei procederá do poder do Parlamento, que, por sua vez, deriva do povo. ${ }^{46}$ Isso representou uma espetacular evolução da concepção política protestante desde Lutero, que ainda reservava ao monarca o direito divino, assim como Calvino o fizera. ${ }^{47}$

\footnotetext{
43 Apud BIÉLER, 1999, p. 81.

44 DAWSON, Christopher. A Divisão da Cristandade - da Reforma Protestante à Era do Iluminismo. São Paulo: É Realizações, 2014. p. 201.

45 Cf. BIÉLER, 1999, p. 81.

${ }^{46}$ Cf. BIÉLER, 1999, p. 82.

47 “[...] visto que o poder dos príncipes lhes vem de Deus.” Cf. CALVINO, 2006, IV, XVI, seção 26, p. 166.
} 


\section{Os revolucionários da Quinta Monarquia}

Ronaldo Cavalcante nomeia seis grupos de partidos e/ou correntes religiosas, dada a já analisada imbricação profunda entre a religião e a política que contracenavam no espaço público inglês do século XVII. São eles: (a) o partido católico ou dos recusantes, que, desde Henrique VIII havia se recusado a aderir ao anglicanismo; (b) o partido anglicano - High Church, aliado da monarquia, teologicamente arminiano, que afirmava a liberdade da vontade humana; (c) o partido anglicano-calvinista - Low Church, episcopal em matéria de governo, mas calvinista na teologia, adepto da monarquia parlamentarista; (d) o partido calvinista estrito - à esquerda do anterior, inspirava-se na igreja genebrina e era puritano; (e) o partido independente - separatista, que rejeitava tanto o episcopalismo como o presbiterianismo, defendendo um sistema de governo rigorosamente congregacionalista. Todos esses partidos eram oriundos, sobretudo, da classe média baixa; (f) o partido da quinta monarquia - composto de vários grupos "que mesclavam visão religiosa apocalíptica com ideias sociais e políticas revolucionárias", como atesta Cavalcante. ${ }^{48}$ Aqui se inserem os quakers (ou shakers), os ranters, os diggers, os seekers e os levellers.

Esses grupos que constituíam a Quinta Monarquia faziam parte das camadas mais baixas da população e, embora tenham apoiado a revolução, não estavam no foco dos benefícios que dela adviriam. A classe burguesa que se aliou a esses grupos nos combates à nobreza depois os alienará dos benefícios e dos centros de poder, inaugurando um longo período de lutas sociais que se estenderão por toda a época da Revolução Industrial. Os levellers eram assim conhecidos por pretenderem nivelar as várias condições sociais na Inglaterra do século XVII. Além das consequências da guerra, a Inglaterra era assolada pela pobreza e pela fome decorrentes de uma colheita perdida em 1648. Rapidamente os grupos populares perceberam que haviam sido alijados do poder e nada havia mudado para eles. Os levellers ergueram a voz para denunciar tal estado de coisas e reivindicar mudanças sociais. Em um de seus panfletos podia-se ler: "Antes éramos governados por um rei, lordes e comuns, agora o somos por um general, uma corte marcial e a Câmara dos Comuns; e peço me digais onde está a diferença!" ${ }^{49}$. Essas ideias radicais ${ }^{50}$ já estavam em curso na Inglaterra desde os lolardos, herdeiros de John Wycliffe, que criticavam a riqueza do clero, os sacramentos, certas cerimônias da igreja e a obrigatoriedade do celibato, dentre outras questões.

Cada vez mais influenciados pelo Novo Exército Modelo, criado por Cromwell, os levellers "exigiam a separação da Igreja e do Estado e a abolição das dízimas; a protecção da pequena propriedade e a reforma da lei dos devedores; e, para assegura-

48 CAVALCANTE, Ronaldo. A Cidade e o Gueto - introdução a uma teologia pública protestante e o desafio do neofundamentalismo evangélico no Brasil. São Paulo: Fonte Editorial, 2010. p. 32-34.

49 Apud HILL, Christopher. O Mundo de Ponta-Cabeça - ideias radicais durante a Revolução Inglesa de 1640. São Paulo: Companhia das Letras, 2002, p. 119.

${ }^{50}$ A palavra radical está sendo utilizada no sentido daqueles que discordavam inteiramente de algumas ortodoxias consolidadas, como proposto por Christopher Hill. Cf. HILL, Christopher. A Bíblia Inglesa e as revoluções do século XVII. Rio de Janeiro: Civilização Brasileira, 2003. p. 280. 
rem tudo isto queriam uma república, a extensão dos direitos parlamentares e o direito de voto para todos os homens" ${ }^{\text {51 }}$. Após a execução do rei, em janeiro de 1649, houve motins no exército e entre os levellers. Rapidamente Cromwell liderou um ataque feroz, esmagando os insubordinados e executando seus chefes em Burford, em maio de $1649 .{ }^{52}$ Após as execuções, o movimento dos levellers se dissipou. Boa parte dos remanescentes juntou-se ao Quakers, ou Sociedade dos Amigos, grupo que seria fundado no ano seguinte, em 1650, por George Fox, e teria na atitude pacifista uma das suas mais importantes marcas. ${ }^{53}$

O grupo dos diggers representava como nenhum outro os interesses dos despossuídos. Tinha como ideal uma reforma agrária. Seus adeptos afirmavam que a vitória do povo havia liberto o solo da Inglaterra e denunciavam os proprietários ricos que cercavam as terras comunais, impedindo o acesso dos pobres a elas. Ameaçavam derrubar essas cercas, dizendo que nenhum homem deveria possuir mais terra do que pudesse arar com as próprias mãos. ${ }^{54}$ Também foram esmagados. Seus líderes eram pacifistas. Um dos mais destacados, Gerrard Winstanley, proclamava um ideal igualitário: "O homem mais pobre da Inglaterra tem tanto direito à terra como o mais rico". E mais: "É esta a servidão de que os pobres se queixam, que os seus irmãos os façam continuarem pobres numa terra onde há fartura para todos". "Todos falam de liberdade, mas muito poucos actuam pela liberdade, e os que o fazem são oprimidos pelos que só falam e professam a liberdade apenas nas palavras. ${ }^{155}$ Esses diggers, que se proclamavam os autênticos levellers, estavam mais à esquerda e advogavam ideias ainda mais radicais. Hill cita o panfleto anônimo Tyranipocrit Discovered (O Desmascaramento do tiranipócrita), de 1649, cujo autor defendia a divisão da propriedade dos ricos entre os pobres todos os anos e atacava a República Inglesa por não haver estabelecido "uma igualdade de bens e de terra", como seria do agrado de Deus e da natureza, e por "não haver tomado providências para educar de maneira igual os filhos de todos os homens, sem distinção" 56 .

As ações militares de Oliver Cromwell não devem esconder que, em matéria de tolerância religiosa, ele avançou bem mais do que a maioria dos membros de sua classe social. Inspirado pela doutrina protestante do sacerdócio universal, ele acreditava que todos deveriam ser respeitados em suas crenças. Para ele, a verdade não era monopólio de nenhuma das seitas. Convidou os presbiterianos a considerar que pudessem estar errados em suas doutrinas. Repudiava o catolicismo, mas na prática era mais tolerante do que na teoria. ${ }^{57}$

51 HILL, Christopher. A Revolução Inglesa de 1640. Lisboa: Presença, 1981. p. 89.

52 Cf. HILL, 2002, p. 119 e HILL, 1981, p. 90.

${ }^{53}$ Cf. HILL, 1981, p. 92.

54 Cf. BIÉLER, 1999, p. 78-79.

55 Apud HILL, 1981, p. 93-94.

56 HILL, 2002, p. 126.

57 Cf. HILL, Christopher. O Eleito de Deus - Oliver Cromwell e a revolução inglesa. São Paulo: Companhia das Letras, 1988. p. 189-190. 
Esse caldeirão religioso que caracterizou a Inglaterra do século XVII estava prenhe de utopias sociais semelhantes àquelas que vão inspirar os teólogos da libertação na América Latina na segunda metade do século XX. Christopher Hill mostra o quanto a Bíblia foi importante para esses diversos grupos em sua estupenda obra A Bíblia Inglesa e as revoluções do século XVII. Mas essa leitura das Escrituras era bastante peculiar e radical nas discordâncias da leitura oficial e ortodoxa. Liam-na a partir da realidade social. Muitos questionavam o valor dos sacramentos, das formas de culto e mesmo das igrejas. Outros negavam a divindade de Cristo, pregavam a salvação universal e outros, uma espécie de panteísmo. Muitos se afastaram de todas as seitas, como os seekers. O próprio Oliver Cromwell parece ter sido acusado de ser um seeker. ${ }^{58}$ Um espírito algo anárquico caracterizava alguns desses grupos, como o dos ranters, ou "faladores", e os antinomistas. Encontros em cervejarias para beber e fumar eram corriqueiros entre eles. "Thomas Edwards cita 'um pregador antinomista londrino', que 'num dia de jejum disse ser melhor os cristãos irem beber numa cervejaria, ou visitar um puteiro, do que respeitar os jejuns ordenados em lei" ",59. Negavam a vinda de Cristo, a existência do inferno, as penas eternas, a existência do pecado e a vida após a morte. Muitos se apresentavam como o próprio Cristo ou Deus. Enfim, o desejo de livre circulação de ideias que caracterizará a modernidade tem na Inglaterra setecentista um importante prenúncio.

\section{Tolerância e democracia}

Além das revoltas burguesas e populares que deram origem à democracia na Inglaterra na segunda metade do século XVII, importantes reflexões filosóficas em torno do sistema político, do Estado, da sociedade e da tolerância religiosa foram gestadas nessa centúria. Nos limites deste texto, cabe aqui ressaltar as ideias em torno da questão da (in)tolerância religiosa.

Decididamente o século da Reforma Protestante (XVI) não é famoso pela defesa da tolerância religiosa, nem entre católicos, nem entre protestantes. Conforme Delumeau, "as guerras civis alemãs da primeira metade do século XVI, e mais ainda as da França após 1562 e a revolta dos Países Baixos, foram antes de tudo guerras de religião" 60 . A intolerância entre católicos e protestantes se fez notar em todas as regiões do continente, e desses para com os anabatistas, os judeus e os muçulmanos. Esses dois últimos, forçados a ser converter à fé cristã por católicos, notadamente em Portugal e Espanha, formaram as comunidades conhecidas dos novos cristãos e dos mouriscos, que ainda assim continuavam sofrendo perseguições. ${ }^{61}$

$\mathrm{Na}$ França, a perseguição foi especialmente atroz contra os protestantes e assolou o país por décadas. Em 24 de agosto de 1572 e nos dias que se seguiram, cerca de

${ }^{58}$ Cf. HILL, 2002, p. 193.

${ }^{59}$ HILL, 2002, p. 200.

${ }^{60}$ DELUMEAU, Jean. Nascimento e Afirmação da Reforma. São Paulo: Pioneira, 1989. p. 162.

${ }^{61}$ Delumeau nota que, entre 1609 e 1614, Felipe III expulsou cerca de 275 mil mouriscos da Espanha. Cf. DELUMEAU, 1989, p. 163. 
30 mil reformados foram mortos em Paris e na província, na terrível Noite de São Bartolomeu. Na Inglaterra, Elizabeth usou de crueldade contra católicos que, ainda vivos, tiveram corações e vísceras arrancados. ${ }^{62}$ Após descrever vários episódios de perseguições entre católicos e protestantes, Delumeau afirma que "é impossível dizer qual dos dois adversários foi mais cruel e em que país se levaram mais longe os requintes de barbaria" ${ }^{63}$. A regra era a intolerância religiosa. Na França foram tantas as guerras e escaramuças que, estando o país desgastado, enfim o rei Henrique IV assinou o célebre Edito de Nantes, em 1591, concedendo liberdade de culto aos reformados, ainda que com algumas restrições. É bem verdade que as hostilidades aos protestantes não cessaram totalmente e, quase cem anos depois, em 1685, Luís XIV assinava o Edito de Fontainebleau, revogando o Edito de Nantes. O documento de Fontainebleau ordenava a destruição das igrejas huguenotes e o fechamento de escolas reformadas. Estima-se que mais de 200 mil huguenotes deixaram a França nas décadas seguintes.

No século XVII, a Guerra dos Trinta Anos devastou o continente. Na Alemanha, país mais afetado, o conflito chegou ao fim com a assinatura da Paz de Westfália, que reafirmou em linhas gerais os acordos da Paz de Augsburgo de 1555 e o princípio cuius regio, eius religio, que estabelecia que a religião do governante seria a do governado. Esse conflito, que começou como disputa de católicos e protestantes em torno da coroa da Boêmia e acabou se alastrando para toda a Europa Central, chegando até mesmo à Espanha, "serviu como prova de que a guerra não era a solução para as diferenças religiosas $[\ldots] "]^{\prime 64}$. A liberdade de consciência e a tolerância religiosa passaram a receber a atenção de pensadores que se destacariam de meados desse século em diante.

O puritano John Milton foi um desses defensores da liberdade de consciência. Em 1644 publicou-se o discurso pela liberdade de imprensa que Milton escreveu para o Parlamento, intitulado Areopagítica. Seu texto foi uma reação à Parliamentary Ordinance for Printing, que visava censurar livros considerados difamatórios contra a religião e o governo. Por trás dessa investida autoritária estavam, especialmente, os presbiterianos, que haviam alcançado, por essa época, projeção no Parlamento e também dominavam a Assembleia de Westminster, reunida por cinco anos e meio a partir de $1^{\circ}$ de julho de 1643 . Contra a tentativa desses presbiterianos de dominar a cena religiosa inglesa, Milton desferiu seu ataque no Areopagítica em defesa da livre circulação de todas as ideias e pela tolerância religiosa. Nessa obra humanística, Milton recorre diversas vezes aos clássicos gregos, a textos bíblicos e da patrística para fundamentar seus argumentos. Apela finalmente ao Parlamento para que cesse toda censura:

Um pouco de generosa prudência, um pouco de tolerância recíproca, um grão de caridade podem unir todos esses esforços numa busca comum e fraternal da verdade. Basta

${ }^{62}$ Cf. DELUMEAU, 1989, p. 163.

${ }^{63}$ DELUMEAU, 1989, p. 163.

${ }^{64}$ DAWSON, 2014, p. 214. 
para isso que abandonemos a tradição prelatícia de sujeitar ao rigor e estreiteza de cânones e preceitos humanos a liberdade de consciência e as demais liberdades cristãs ${ }^{65}$.

O texto de Milton não teve repercussão nos seus dias. Somente meio século depois a Ordinance foi revogada. Mas, quando isso aconteceu, o ideal de liberdade expresso no Areopagítica foi lembrado e seu conteúdo serviu como inspiração para muitos outros que se alinhariam na defesa das liberdades fundamentais.

Homens como John Smyth e Thomas Helwys, fundadores da primeira comunidade batista da Inglaterra, foram incansáveis defensores da democracia e da liberdade religiosa contra o que consideravam uma tirania dos bispos anglicanos. Por influência dos menonitas da Holanda, país em que viveu nos tempos de exílio, Smyth tornou-se um defensor da separação entre igreja e Estado. Richard Overton publicou, em 1646, a obra An Arrow against all Tyrants or Tyranny. Defensor dos ideais dos levellers, foi preso por defender a democracia. Henry Marten, membro da Câmara dos Comuns, republicano extremado, ligado aos levellers, atacou os presbiterianos que se consideravam a elite intelectual. Foi acusado de ateísmo por afirmar que a humanidade não detinha capacidade cognitiva para dizer o que ou quem era Deus. Isso implicava, segundo ele, tolerância religiosa para com todas as religiões, pois ninguém guardava o monopólio da verdade religiosa. Essa liberdade incluiria os católicos e as demais religiões. No entanto, o caso mais impressionante de defesa da plena liberdade religiosa nesses dias foi o protagonizado por Roger Williams, fundador da cidade de Providence na colônia de Rhode Island e da primeira congregação batista na América. Em sua obra The Bloudy Tenent of Persecution for Cause of Conscience, publicada em 1644, mesmo ano da Areopagítica de Milton, foi muito além da maioria dos seus contemporâneos, defendendo uma tolerância religiosa extrema que incluía os católicos, judeus, turcos, pagãos e os direitos dos indígenas americanos. ${ }^{66}$

Os independentes foram entusiastas da tolerância num nível bastante acima dos episcopalianos e presbiterianos. Sobre a relação dos independentes e presbiterianos, destaca-se que, em muitos sentidos, ambos faziam parte da mesma matriz religiosa, com posições radicais regadas pelo protestantismo continental, que os congregava no repúdio a tudo que lembrasse o culto católico: o altar, as vestes litúrgicas "e especialmente a sobrepeliz" ${ }^{67}$. Ambos eram hostis ao episcopado e são justificadamente chamados de puritanos..$^{68}$ Mas, diferentemente dos independentes, os presbiterianos eram ciosos de um biblicismo que os conduzira a posições dogmáticas. Já os independentes relativizavam o valor das Escrituras, sempre desconfiados da letra da lei, inclinando-se a valorizar a inspiração interior e a iluminação do Espírito Santo. Esse antidog-

${ }^{65}$ MILTON, John. Areopagítica - discurso pela liberdade de imprensa ao Parlamento da Inglaterra. Rio de Janeiro: Topbooks, 1999. p. 161.

${ }^{66}$ Cf. WILLIAMS, Roger. The Bloudy Tenent of Persecution for cause of conscience. London: J. Haddon, 1848. p. 141-142.

${ }^{67}$ DELUMEAU, 1989, p. 230.

${ }^{68} \mathrm{O}$ termo surgiu por volta de 1565 , aplicado inicialmente aos presbiterianos ingleses. Cf. DELUMEAU, 1989, p. 230. 
matismo herdado de antigas influências humanistas e anabatistas alimentou entre os independentes ao mesmo tempo o sectarismo e a tolerância religiosa, encontrada entre os quakers e os batistas, por exemplo. "Por terem intenção de constituir 'sociedades de fiéis chamados pela palavra de Deus, separados do mundo e de seus caminhos de perdição', os Batistas foram eloqüentes defensores da tolerância religiosa." ${ }^{\circ 9}$

Entre os quakers, William Penn (1644-1718) foi um dos mais destacados defensores do pacifismo, da democracia e da tolerância religiosa. Penn recebeu terras nas colônias americanas do rei Carlos II como pagamento de uma dívida real para com seu pai. Foi nessas terras que ele fundou a colônia conhecida como Pensilvânia. Convicto dos direitos individuais de todos os seres humanos, William Penn tornou a Pensilvânia a colônia mais tolerante de todas. Lá foram acolhidos luteranos alemães perseguidos em territórios controlados por católicos; alemães católicos discriminados em seu país; menonitas; amish; quakers, huguenotes e judeus. Inspirado pelas reuniões quakers em que todos podiam fazer uso da palavra, Penn idealizou um Estado cujo poder emanasse do "discurso do povo". Ele e seus irmãos quakers se destacaram também, entre todos os protestantes desse período, pela defesa da abolição da escravatura. Max Weber reconhece que "a única seita cristã que lutou de maneira permanente e constante contra a escravatura foi a dos quacres, uma vez que nem os calvinistas, nem os católicos, nem alguma outra denominação defenderam conseqüente e constantemente a idéia de abolição"

Cabe ainda ressaltar o pensamento de John Locke acerca da tolerância. Em sua Carta Sobre a Tolerância, ele foca especificamente no tema da religião. Fundamentado no jusnaturalismo, Locke acreditava no direito natural de todos ${ }^{71}$ para decidir no que queriam crer. Para ele, "o cuidado das almas não está sob responsabilidade civil, assim como de nenhum outro homem. [...] Parece que Deus jamais concedeu tal autoridade a um homem, para exercê-la sobre outro, de modo a forçá-lo à sua religião" ${ }^{\text {"72 }}$. Além disso, nem mesmo o povo poderia conceder essa autoridade aos magistrados, "porque nenhum homem pode assim abandonar os cuidados com sua própria salvação, de modo a cegamente deixar que algum outro, seja príncipe ou súdito, prescreva-lhe a fé ou os rituais que deve abraçar". Para Locke, "toda a vida e o poder da religião verdadeira consistem na persuasão interna e completa da mente; e fé não é fé sem crença" "73. Não apenas os protestantes devem ter liberdade de crença. O raciocínio de Locke é que, se quisermos dar aos magistrados o poder de coibir as religiões consideradas pelos protestantes como pagãs ou idólatras, esse mesmo magistrado poderá voltar-se contra os protestantes, pois "uma vez que se permita intro-

${ }^{69}$ DELUMEAU, 1989, p. 236.

${ }^{70}$ WEBER, Max. A Gênese do Capitalismo Moderno. São Paulo: Ática, 2006. p. 43-44.

${ }^{71}$ Ressalve-se que "todos" aqui é bastante relativo no pensamento de Locke. Ele exclui desse "todos" os católicos, os homens primitivos (indígenas), os mendigos, os escravos etc. Portanto seu pensamento precisa ser considerado numa perspectiva de evolução das ideias. Isso feito, ele pode ser listado entre aqueles que ajudaram a fundar o estado democrático moderno e os direitos humanos.

${ }_{72}$ LOCKE, John. Carta Sobre a Tolerância. São Paulo: Hedra, 2007. p. 39.

${ }^{73}$ LOCKE, 2007, p. 39. 
duzir qualquer coisa na religião através de leis e punições, não haverá limites para as mudanças $[\ldots]$ ". 74 . Para Locke, "a liberdade de consciência é direito natural de todo homem" "75, e se guerras e outros absurdos são imputados às religiões, as causas têm que ser buscadas em outras fontes. As causas estão na "recusa da tolerância com os que são de opinião diferente, o que deveria ser reconhecido, que tem produzido todas as batalhas e guerras que ocorrem no mundo cristão, sob o pretexto da religião" ${ }^{\text {"76 }}$.

\section{Considerações finais}

As teorias políticas protestantes são bastante amplas e complexas, dado o contexto no qual elas emergiram. Como vimos acima, o reformador João Calvino evoluiu seu pensamento político conforme mudanças nesse campo iam sendo engendradas. De uma subserviência pacífica, ele chegou à defesa da resistência armada em caso de grave ameaça à fé e à pregação do evangelho.

Calvinistas ingleses e escoceses foram além, afirmando que não apenas os magistrados inferiores poderiam legitimamente resistir aos monarcas, mas também o próprio povo quando se sentisse ameaçado pelos governantes. George Buchanan (1506-1582) foi quem fez a transposição de argumentos teológicos que justificassem tal nível de resistência para um argumento secular, puro e simples. Para ele, como vimos, o poder dos governantes procede do povo, que a ele não abdica e, portanto, pode tomá-lo de volta.

A consolidação dessas novas teorias políticas que tiveram origem entre os reformadores calvinistas ocorrerá a partir do século XVII, especialmente na Inglaterra, dos puritanos independentes, dos movimentos populares conhecidos como a Quinta Monarquia, e dos ideais de tolerância religiosa surgidos em resposta às guerras de religião. Será ali que a democracia moderna sairá do campo da especulação filosófica para sua concretização, notadamente a partir do estabelecimento da monarquia parlamentarista, ao final da Revolução Gloriosa de 1688/89.

\section{Referências}

ALTHUSIUS, Johannes. Politica. Rio de Janeiro: Topbooks, 2003.

BIÉLER, André. A Força Oculta dos Protestantes. São Paulo: Cultura Cristã, 1999.

CALVINO, João. As Institutas. São Paulo: Cultura Cristã, 2006. Livro IV.

CALVINO, João. Daniel. São Paulo: Parakletos, 2000. v. I.

CAVALCANTE, Ronaldo. A Cidade e o Gueto - introdução a uma teologia pública protestante e o desafio do neofundamentalismo evangélico no Brasil. São Paulo: Fonte Editorial, 2010.

DAWSON, Christopher. A Divisão da Cristandade - da Reforma Protestante à Era do Iluminismo. São Paulo: É Realizações, 2014.

DELUMEAU, Jean. Nascimento e Afirmação da Reforma. São Paulo: Pioneira, 1989.

\footnotetext{
${ }^{74}$ LOCKE, 2007, p. 70.

${ }^{75}$ LOCKE, 2007, p. 85.

${ }^{76}$ LOCKE, 2007, p. 92.
} 
HILL, Christopher. A Bíblia Inglesa e as revoluções do século XVII. Rio de Janeiro: Civilização Brasileira, 2003. . A Revolução Inglesa de 1640. Lisboa: Presença, 1981.

Letras, 1988. . O Eleito de Deus - Oliver Cromwell e a revolução inglesa. São Paulo: Companhia das . O Mundo de Ponta-Cabeça-ideias radicais durante a Revolução Inglesa de 1640. São Paulo: Companhia das Letras, 2002.

HÖPFL, Harro. Lutero e Calvino - sobre a autoridade secular. São Paulo: Martins Fontes, 2005. LOCKE, John. Carta Sobre a Tolerância. São Paulo: Hedra, 2007.

MILTON, John. Areopagítica - discurso pela liberdade de imprensa ao Parlamento da Inglaterra. Rio de Janeiro: Topbooks, 1999.

MORAES, Gerson Leite de. Entre a Bíblia e a Espada - uma análise da filosofia e da teologia política em João Calvino. São Paulo: Mackenzie, 2014.

RIBEIRO, Renato Janine. Apresentação. In: HILL, Christopher. O Mundo de Ponta-Cabeçaidéias radicais durante a Revolução Inglesa de 1640. São Paulo: Companhia das Letras, 2002. ROMANO, Roberto. Os Monarcômacos. 2008. Disponível em: $<$ https://robertoromanosilva. wordpress.com/2010/03/11/os-monarcomacos/>. Acesso em: 31 ago. 2017.

SILVESTRE, Armando Araújo. Calvino e a Resistência ao Estado. São Paulo: Mackenzie, 2002. SKINNER, Quentin. As Fundações do Pensamento Político Moderno. São Paulo: Companhia das Letras, 2009.

WEBER, Max. A Gênese do Capitalismo Moderno. São Paulo: Ática, 2006.

WILLIAMS, Roger. The Bloudy Tenent of Persecution for cause of conscience. London: J. Haddon, 1848. 